\title{
Total Petroleum Hydrocarbon Degradation and BTEX Leaching in Soils after Application of Oil-Base Drilling Mud: Impact of Application Rate, Rainfall Regime, and Time
}

\author{
Andrew H Whitaker ${ }^{1}$ and Chad J Penn*2 \\ ${ }^{1}$ Department of Crop and Soil Sciences, North Carolina State University, USA \\ ${ }^{2}$ United States Department of Agriculture-Agricultural Research Service, USA
}

Received: 畊 February 08, 2018; Published: 眥 February 16, 2018

*Corresponding author: Chad J Penn, United States Department of Agriculture-Agricultural Research Service. 275 S. Russell St., West Lafayette, Indiana, United States

\begin{abstract}
Increases in oil and gas drilling have resulted in large quantities of oil base "mud" (OBM) to be disposed of. Land application of OBM to agricultural land is a common disposal technique that presents agronomic and environmental challenges since the material is rich in total petroleum hydrocarbons (TPH). Leaching of lower molecular weight hydrocarbons, mainly benzene, toluene, ethylbenzene, and xylene (BTEX), is a concern due to their relatively low octanol: water partition coefficients. The objective of this study was to determine the effect of rainfall regime and TPH loading rate on TPH degradation and BTEX leaching after OBM application. An OBM was characterized for TPH, BTEX, and trace metals. A soil column study was conducted where OBM was applied at five loading rates $(0,22,000,45,000,67,000$, and 90,000 kg TPH ha-1) and was subjected to four moisture regimes. OBM samples were taken at day $0,7,30,60$, and 91 to monitor TPH degradation. Leachate samples were taken at day $0,14,28,35,49,56,63,77$, and 84 to monitor electrical conductivity (EC), pH, metal concentrations, and BTEX concentrations. After 60 days, a maximum TPH degradation of $35 \%$ was measured. Leachate BTEX concentrations increased as TPH application rate increased and was mostly undetectable by day 28. Leachate EC increased over time and with increasing TPH rates. TPH rate had no effect on leachate pH. OBM loading rates had the greatest effect on TPH degradation and BTEX leaching. Under our experimental conditions, little risk of BTEX leaching from land applied OBM was observed.
\end{abstract}

Abbreviations: OBM: Oil-Base Mud; TPH: Total Petroleum-Based Hydrocarbons; BTEX: Benzene, Toluene, Ethylbenzene, and Xylene; OCC: Oklahoma Corporation Commission (OCC); EC: Electrical Conductivity

\section{Introduction}

Currently, the United States is experiencing a boom in oil and gas drilling. In 2013, there were approximately 910,000 and 4,900 onshore and offshore oil and natural gas wells, respectively, that produced nearly 16 million $\mathrm{m}^{3}$ of oil and 665 billion $\mathrm{m}^{3}$ of natural gas [1]. When drilling activity increases, an increase in the production of drilling wastes result, specifically drilling fluids and drill cuttings (i.e. "mud"). A study conducted by the American Petroleum Institute in 1995 estimated that around 150 million barrels of drilling wastes were generated on-shore in the United States alone [2]. In the oil and gas industry, drilling mud is utilized to help cool the drill bit, maintain borehole pressure, and aid in bringing drill cuttings to the surface where the fluids and cuttings can then be separated [3]. Drilling muds are composed of a base liquid (water or diesel fuel) with other potential additives such as bentonite, barium sulfate, cotton seed hulls, and calcium hydroxide, which may be used for specific drilling conditions [4]. When diesel fuel is the base solution for drilling mud, the mud is called "oil base mud" (OBM). OBM is typically utilized when drilling depths exceed $1500 \mathrm{~m}$ or during horizontal drilling. OBM is re-used by drillers for as long as possible due to the high cost of production. 
Once the OBM is spent and can no longer be used in drilling, it must be properly disposed of. On average, $340 \mathrm{~m}^{3}$ of OBM are produced from a typical southeastern Oklahoma natural gas well at depths ranging from 4200-5200 m deep [5]. Some of the products added to the mud may be harmful, and therefore need to be properly handled [6]. Hence, there are two options for mud disposal: land application and burial. Burial of the waste can occur onsite in "reserve pits" or at commercial facilities. In general, onsite reserve pits are only allowed for water-base mud, not OBM. Land application is the most common method of OBM disposal in Oklahoma. The purpose of land applying OBM is to allow soil microorganisms to degrade petroleum hydrocarbons (i.e. "total petroleum hydrocarbons"; TPH). In Oklahoma, regulations for the land application of OBM are controlled by the Oklahoma Corporation Commission (OCC). OBM land application rates are limited based on loading of TPH, chlorides, and solids (Oklahoma administrative code and register, Title 165:10-7-26). Furthermore, the OCC requires that OBM be mixed with a bulking material such as lime or gypsum, at a ratio of 3:1 OBM: bulking material. Although TPH is taken into account when applying OBM, there is still a potential for the over-application of low molecular weight hydrocarbons: benzene, toluene, ethylbenzene, and xylene (BTEX). Benzene is a known human carcinogen and all BTEX components are known to cause neurological effects [7]. BTEX chemicals are prone to leaching due to their relatively low octanol: water partition coefficients [8] and therefore pose a threat to drinking water. In addition to loading limits, there are also several site suitability requirements such as soil texture, depth to groundwater and limiting layers, slope, soil sodium concentrations, and proximity to surface waters. Although thousands of hectares are currently receiving OBM, there has been relatively little research conducted on the degradation of TPH and the leaching of BTEX after land application of OBM.

Uncontrolled application rates could lead to soil TPH concentrations that would be detrimental to soil and water quality leading to environmental issues. Penet et al. [9] conducted a study that examined biodegradation of hydrocarbons in the soil and found that microbes degraded the straight chained hydrocarbons faster than the branched chained hydrocarbons. Dou et al. [10] conducted a study focused on anaerobic BTEX degradation under nitrate reducing conditions and determined that BTEX could be biodegraded to undetectable concentrations in 70 days if initial concentrations of BTEX were $\leq 100 \mathrm{mg} \mathrm{kg}^{-1}$ soil. Very few studies have dealt with TPH degradation and BTEX leaching in soils after land application of OBM. Due to the hazardous risks of TPH, specifically BTEX toxicity to humans and to the environment, there is a need to examine TPH degradation and BTEX leaching in soils after land application of OBM under different scenarios such as multiple loading rates and moisture regimes. Thus, the objective of this study was to determine the impact of rainfall regime and TPH loading rates from OBM application on TPH degradation and BTEX leaching.

\section{Materials and Methods}

A soil column study was conducted in Stillwater, Oklahoma in a temperature controlled greenhouse. Soils were contained in 240 aluminum soil columns that were $30.5 \mathrm{~cm}$ tall and $7.6 \mathrm{~cm}$ in diameter. Columns were filled $15.2 \mathrm{~cm}$ with a sandy loam soil from Perkins, Oklahoma. The soil series used in this experiment was Dougherty loamy fine sand (Loamy, mixed, active, thermic Arenic Haplustalfs). Glass wool and aluminum screen with a 7.6 $\mathrm{cm}$ hose clamp was placed on the bottom of all columns in order to prevent soil from leaching out. The experimental design was a randomized complete block with factorial structure. There were three replications of each treatment. The OBM sample was characterized for $\mathrm{pH}$, electrical conductivity (EC), total soluble salts (TSS), and total solids content, total and water extractable metals and total chloride. OBM pH and EC were measured using $\mathrm{pH}$ and EC probes with a solid: solution ratio of 1:5 and an equilibration time of $45 \mathrm{~min}$. The OBM was analyzed for total $\mathrm{P}, \mathrm{K}, \mathrm{Mg}, \mathrm{Ca}, \mathrm{Na}, \mathrm{Mn}, \mathrm{Cu}$, $\mathrm{Fe}, \mathrm{Zn}, \mathrm{S}, \mathrm{Al}, \mathrm{Ni}, \mathrm{B}, \mathrm{As}, \mathrm{Cd}, \mathrm{Cr}, \mathrm{Ba}, \mathrm{Pb}$, and Mo using the EPA 3050 acid digestion method followed by solution analysis with inductively coupled argon plasma analyzer [ICP-AES; Spectro Ciros, Mahwah, NJ]. Water extractable metals and total chloride were extracted with de-ionized (DI) water using a 1:10 solid: solution ratio for 1 hour followed by ICP-AES analysis on the metals and colorimetric flow-injection analysis (Lachat Quick Chem 8000, Loveland, CO) for chloride.

Prior to the application of OBM, BTEX and TPH concentrations were analyzed. Total petroleum hydrocarbons were extracted with hexane at 1:10 solids: solvent ratio, plus addition of $0.5 \mathrm{~g} \mathrm{Na}_{2} \mathrm{SO}_{4}$ for 5 minutes on a reciprocating shaker followed by centrifugation for 10 minutes. Five $\mathrm{mL}$ of the resulting supernatant was equilibrated for 2 minutes with $1 \mathrm{~g}$ of silica gel in a glass tube for removal of polar organic compounds. The solution was then analyzed for TPH using infrared spectroscopy (ASTM method D 7066) with the Infra Cal TOG/TPH analyzer (model HATR-T2, Wilks Enterprise Inc., East Norwalk, CT). Random samples were duplicated and check samples were utilized in order to assure precise and accurate results. Initial benzene, toluene, ethylbenzene, o-xylene, $\mathrm{m}, \mathrm{p}$-xylene and TPH concentrations were 2.65, 23, 35, 64, 94, and 161,558 mg kg1. Treatments included five TPH (i.e. OBM) loading rates and four rainfall regimes.

Soil columns were harvested for OBM analysis of TPH at four different times. Oil-base mud was applied onto an aluminum screen which rested on top of the soil that allowed soil to contact the OBM, yet prevented mixing and dilution of the applied OBM TPH with the soil. This allowed for removal of the OBM throughout the incubation in order to test for TPH degradation. Oil-base mud loading rates were applied to achieve a TPH application of 90,000, $67,000,45,000,22,000$, and 0 (control) kg TPH ha-1. Each column was treated with one leaching event per month which consisted of application of 1.5 pore volumes of tap water. In this study, the term 
"moisture regime" indicates the number of non-leaching wetting events that occurred per month. Moisture regime levels 4, 3, 2, and 1 had 3, 2, 1, and 0 non-leaching wetting events per month, which consisted of 0.5 pore volumes of tap water. These non-leaching wetting events are important because they can move soluble constituents within the column, but not out of the column, as well as provide moisture for microorganisms that may degrade TPH. Collected leachate was analyzed for benzene, toluene, ethylbenzene, and xylene using the EPA 8021B method followed by solution analysis with gas chromatography with a photo ionization detector (GC-PID). In addition, leachate was also analyzed for $\mathrm{Na}, \mathrm{Ca}, \mathrm{Mg}, \mathrm{K}$, S04, B, P, Fe, Zn, Cu, Mn, Al, Mo, As, Cd, Co, Cr, Pb, and Ba via ICP-AES. OBM was harvested on top of the aluminum screens at $7,30,60$, and 90 days after application and analyzed for TPH concentrations ( $\mathrm{mg} \mathrm{TPH} \mathrm{kg} \mathrm{mud}^{-1}$ ) with the Wilks TOG/TPH IR Analyzer. The BTEX concentrations in harvested OBM samples were measured 7 days after application.

\section{Statistics}

Analyses of Variance (ANOVA) methods were utilized in PROC GLM [11] to analyze the effects of OBM loading rates and moisture regimes on TPH degradation and BTEX leaching. When the main effects or interactions of OBM loading rates and moisture regimes were significant, treatment means were separated using pair wise comparisons via Duncan's multiple range test. Statistical decisions were made at $\alpha=0.05$. The data analysis for this paper was computed using SAS software.

\section{Results and Discussion}

\section{Background Soil Properties}

Table 1: Background chemical analysis of the soils used in the BTEX leaching column study.

\begin{tabular}{|c|c|}
\hline Soil Texture & Sandy Loam \\
\hline $\mathrm{pH}$ & 6.8 \\
\hline Electrical Conductivity $\left(\mathrm{mS} \mathrm{cm}^{-1}\right)$ & 0.69 \\
\hline Total Soluble Salts $\left(\mathrm{mg} \mathrm{L}^{-1}\right)$ & 454.1 \\
\hline N-NO3- $\left(\mathrm{kg} \mathrm{ha}^{-1}\right)$ & 8 \\
\hline Soil Test Phosphorus $\left(\mathrm{kg} \mathrm{ha}^{-1}\right)$ & 6 \\
\hline Soil Test Potassium $\left(\mathrm{kg} \mathrm{ha}^{-1}\right)$ & 147 \\
\hline Ca $\left(\mathrm{kg} \mathrm{ha}^{-1}\right)$ & 1789 \\
\hline Mg $\left(\mathrm{kg} \mathrm{ha}^{-1}\right)$ & 297 \\
\hline S-SO4-2 $\left(\mathrm{kg} \mathrm{ha}^{-1}\right)$ & 9 \\
\hline
\end{tabular}

The soil utilized in the BTEX leachate study was a sandy loam texture (Table 1) which has great potential for the leaching of soluble constituents. The OCC states in the Oklahoma administrative code and register, Title 165:10-7-26 that OBM must be incorporated into the soil after application; incorporation of the OBM leads to increased mixing (dilution) of the OBM into the soil and faster hydrocarbon degradation. Due to the large hydraulic conductivity of the sandy loam soil and the fact that the OBM was not incorporated made this study a worst-case scenario for land application of OBM with respect to BTEX leaching and hydrocarbon degradation. The background soil had N-NO3-, P, and K concentrations of 8, 6, and $147 \mathrm{~kg} \mathrm{ha}^{-1}$, respectively. Soil $\mathrm{pH}$ was 6.8 and was in the optimal range for microbial degradation and limiting metal migration in the soil [12].

\section{Background Oil-Base Mud Properties}

Table 2: Characterization of the raw (solids plus liquid) and the water extractable portion of the oil-base mud (OBM) used in the BTEX leaching column study. All water extraction results were obtained by using a 1:10 solids to DI water ratio unless otherwise noted.

\begin{tabular}{|c|c|c|c|}
\hline \multicolumn{2}{|c|}{ Raw OBM Concentration } & \multicolumn{2}{|c|}{ Oil-Based Mud Water Extraction } \\
\hline TPH (mg kg $\left.{ }^{-1}\right)$ & 161,558 & $\mathrm{EC}\left(\mathrm{mS} \mathrm{cm}^{-1}\right)(1: 3)$ & 6.91 \\
\hline Benzene $\left(\mathrm{mg} \mathrm{kg}^{-1}\right)$ & 2.65 & $\mathrm{pH}(1: 3)$ & 11.3 \\
\hline Toluene $\left(\mathrm{mg} \mathrm{kg}^{-1}\right)$ & 23.0 & $\begin{array}{l}\text { Total Soluble Salts (mg } \\
\left.\mathrm{L}^{-1}\right)\end{array}$ & 4561 \\
\hline $\begin{array}{l}\text { Ethylbenzene (mg } \\
\left.\qquad \mathrm{kg}^{-1}\right)\end{array}$ & 35.0 & Benzene $\left(\mathrm{mg} \mathrm{kg}^{-1}\right)$ & 0.15 \\
\hline o-Xylene $\left(\mathrm{mg} \mathrm{kg}^{-1}\right)$ & 64.0 & Toluene $\left(\mathrm{mg} \mathrm{kg}^{-1}\right)$ & 1.12 \\
\hline $\begin{array}{c}\text { m, p-Xylene (mg } \\
\text { kg-1) }^{-1} \text { ) }\end{array}$ & 94.0 & Ethylbenzene $\left(\mathrm{mg} \mathrm{kg}^{-1}\right)$ & 0.49 \\
\hline \% Solids Content & 74.0 & $\mathrm{o}$-Xylene $\left(\mathrm{mg} \mathrm{kg}^{-1}\right)$ & 0.79 \\
\hline $\mathrm{Na}\left(\mathrm{mg} \mathrm{kg}^{-1}\right)$ & 2395.4 & m, p-Xylene $\left(\mathrm{mg} \mathrm{kg}^{-1}\right)$ & 1.32 \\
\hline $\mathrm{Ca}\left(\mathrm{mg} \mathrm{kg}^{-1}\right)$ & 55518.1 & $\mathrm{Na}\left(\mathrm{mg} \mathrm{kg}^{-1}\right)$ & 1616.9 \\
\hline $\operatorname{Mg}\left(\mathrm{mg} \mathrm{kg}^{-1}\right)$ & 5867.1 & $\mathrm{Ca}\left(\mathrm{mg} \mathrm{kg}^{-1}\right)$ & 6240.0 \\
\hline $\mathrm{K}\left(\mathrm{mg} \mathrm{kg}^{-1}\right)$ & 1962.9 & $\operatorname{Mg}\left(\mathrm{mg} \mathrm{kg}^{-1}\right)$ & 0.0 \\
\hline $\mathrm{SO}^{-2}-\mathrm{S}\left(\mathrm{mg} \mathrm{kg}^{-1}\right)$ & 14925.8 & $\mathrm{~K}\left(\mathrm{mg} \mathrm{kg}^{-1}\right)$ & 259.0 \\
\hline$P\left(\mathrm{mg} \mathrm{kg}^{-1}\right)$ & 312.6 & $\mathrm{SO}^{-2}-\mathrm{S}\left(\mathrm{mg} \mathrm{kg}^{-1}\right)$ & 3145.5 \\
\hline $\mathrm{Fe}\left(\mathrm{mg} \mathrm{kg}^{-1}\right)$ & 17681.3 & $\mathrm{P}\left(\mathrm{mg} \mathrm{kg}^{-1}\right)$ & 1.3 \\
\hline $\mathrm{Zn}\left(\mathrm{mg} \mathrm{kg}^{-1}\right)$ & 61.1 & $\mathrm{Fe}\left(\mathrm{mg} \mathrm{kg}^{-1}\right)$ & 0.5 \\
\hline $\mathrm{Cu}\left(\mathrm{mg} \mathrm{kg}^{-1}\right)$ & 71.1 & $\mathrm{Zn}\left(\mathrm{mg} \mathrm{kg}^{-1}\right)$ & 0.0 \\
\hline $\operatorname{Mn}\left(\mathrm{mg} \mathrm{kg}^{-1}\right)$ & 414.1 & $\mathrm{Cu}\left(\mathrm{mg} \mathrm{kg}^{-1}\right)$ & 0.2 \\
\hline $\mathrm{Al}\left(\mathrm{mg} \mathrm{kg}^{-1}\right)$ & 8232.3 & $\operatorname{Mn}\left(\mathrm{mg} \mathrm{kg}^{-1}\right)$ & 0.0 \\
\hline $\mathrm{Ni}\left(\mathrm{mg} \mathrm{kg}^{-1}\right)$ & 17.7 & As $\left(\mathrm{mg} \mathrm{kg}^{-1}\right)$ & 0.0 \\
\hline B $\left(\mathrm{mg} \mathrm{kg}^{-1}\right)$ & 46.6 & $\mathrm{Cd}\left(\mathrm{mg} \mathrm{kg}^{-1}\right)$ & 0.0 \\
\hline As $\left(\mathrm{mg} \mathrm{kg}^{-1}\right)$ & 0.1 & $\mathrm{Cr}\left(\mathrm{mg} \mathrm{kg}^{-1}\right)$ & 0.0 \\
\hline $\mathrm{Cd}\left(\mathrm{mg} \mathrm{kg}^{-1}\right)$ & 0.0 & $\mathrm{Ba}\left(\mathrm{mg} \mathrm{kg}^{-1}\right)$ & 1.68 \\
\hline $\mathrm{Cr}\left(\mathrm{mg} \mathrm{kg}^{-1}\right)$ & 20.7 & $\mathrm{~Pb}\left(\mathrm{mg} \mathrm{kg}^{-1}\right)$ & 0.07 \\
\hline $\mathrm{Ba}\left(\mathrm{mg} \mathrm{kg}^{-1}\right)$ & 971.9 & Co $\left(\mathrm{mg} \mathrm{kg}^{-1}\right)$ & 0.0 \\
\hline $\mathrm{Pb}\left(\mathrm{mg} \mathrm{kg}^{-1}\right)$ & 21.9 & $\mathrm{Cl}\left(\mathrm{mg} \mathrm{kg}^{-1}\right)$ & 8549.34 \\
\hline Co $\left(\mathrm{mg} \mathrm{kg}^{-1}\right)$ & 0.0 & & \\
\hline
\end{tabular}

The initial chemical analysis of the raw OBM and water extractable portion are listed in Table 2. The raw OBM had an initial TPH concentration of $161,558 \mathrm{mg} \mathrm{TPH} \mathrm{kg}^{-1}$ and consisted of $74 \%$ solids. The raw OBM had a benzene concentration of $2.65 \mathrm{mg} \mathrm{kg}^{-1}$ which was higher than the inhalation limit of $0.8 \mathrm{mg} \mathrm{kg}^{-1}$ established by the U.S. EPA [13] and for risk to groundwater by leaching $(0.03$ 
$\mathrm{mg} \mathrm{kg}^{-1}$; [14]). The water-soluble benzene concentration $(0.015 \mathrm{mg}$ $\mathrm{L}^{-1}$ ) was higher than the groundwater limit of $0.005 \mathrm{mg} \mathrm{L}^{-1}$ set by the Oklahoma Guardian [15]. Calcium was the dominant cation in both the raw solid and water extractable portion of the OBM. Chloride and sulfate were the two most abundant anions in the water extractable portion of the OBM. All heavy metal concentrations $(\mathrm{Zn}, \mathrm{Cu}, \mathrm{Ni}$, $\mathrm{As}, \mathrm{Cd}, \mathrm{Cr}$, and $\mathrm{Pb}$ ) measured in the raw OBM were below EPA 503 thresholds for "exceptional quality" bio solids, indicating that there is only slight risk of metals contamination from land application of this OBM sample [16]. In fact, heavy metal concentrations in the OBM were in the normal range typically found in soils [17].

\section{Degradation of total petroleum-based hydrocarbons with oil-base mud application}

The main effects of TPH rate, moisture regime, sampling day (i.e. time), and the two-way interaction of rate*day were significant at $\alpha=0.05$ for TPH concentration ( $\mathrm{mg} \mathrm{kg}^{-1} \mathrm{OBM}$ ). An ANOVA table with the complete list of main effects and interactions for TPH concentration (mg kg-1 OBM) are listed in Table 3.The main effect of TPH application rate ( $\mathrm{kg}$ TPH ha-1) on overall TPH concentration (mg TPH kg-1 OBM) was significant $(\mathrm{P} \leq 0.05)$ and is shown in more detail in Table 4 (averaged across all sampling times and moisture regimes). TPH application rate $1\left(22,000 \mathrm{~kg}\right.$ TPH ha $\left.{ }^{-1}\right)$ had a significantly lower TPH concentration than all other rates and was closely followed by application rate $2\left(45,000 \mathrm{~kg} \mathrm{TPH} \mathrm{ha}^{-1}\right)$ which was also significantly different than all other application rates. Application rate $3(67,000 \mathrm{~kg}$ TPH ha-1) and rate $4(90,000 \mathrm{~kg}$ TPH $\mathrm{ha}^{-1}$ ) had the highest TPH concentrations but were not significantly different than each other. The decreased TPH degradation displayed by application rates 3 and 4 were likely due to reduced contact between OBM and the soil surface (i.e. lower OBM: soil contact area), resulted in less TPH degradation $[18,19]$.

Table 3: Mean total petroleum hydrocarbon (TPH) concentrations $\left(\mathrm{mg} \mathrm{kg}^{-1} \mathrm{OBM}\right)$ in the surface applied OBM averaged across moisture regime and sampling day for each TPH application rate. OBM loading rates were applied at 90,000, 67,000, 45,000, 22,000, and 0 (control) $\mathrm{kg} \mathrm{TPH} \mathrm{ha-1.} \mathrm{The} \mathrm{treatments} \mathrm{were} \mathrm{subjected} \mathrm{to}$ four different moisture regimes. OBM was sampled at 0, 7, 30, 60, and 90 days after application. Uppercase letters represent mean separation of TPH concentration ( $\mathrm{mg} \mathrm{TPH} \mathrm{kg}^{-1}$ mud) between $\mathrm{TPH}$ rates. Statistical decisions were $\mathrm{mad}$ at $\mathrm{P}=0.05$.

\begin{tabular}{|c|c|c|}
\hline Variable & DF & Pr $>$ F \\
\hline rep & 2 & 0.1175 \\
\hline rate & 3 & $<0.001$ \\
\hline moisture & 3 & 0.0301 \\
\hline day & 4 & $<0.0001$ \\
\hline rate*moisture & 9 & 0.0686 \\
\hline rate*day & 12 & $<0.0001$ \\
\hline rate*moisture*day & 36 & 0.1721 \\
\hline
\end{tabular}

Table 4: Mean total petroleum hydrocarbon (TPH) concentration (mg TPH kg-1 OBM) at each sample day averaged over moisture regime and $\mathrm{TPH}$ application rate. OBM loading rates were applied at 90,000, 67,000, 45,000, 22,000, and 0 (control) $\mathrm{kg} \mathrm{TPH}$ $\mathrm{ha}^{-1}$. The treatments were subjected to four different moisture regimes. OBM was sampled at $0,7,30,60$, and 91 days after application. Uppercase letters represent mean separation of $\mathrm{TPH}$ degradation (mg TPH kg-1 OBM) between all sample days. Statistical decisions were made at $\mathrm{P}=0.05$.

\begin{tabular}{|c|c|}
\hline $\begin{array}{c}\text { TPH application rate (kg TPH } \\
\mathbf{h a}^{-1} \text { ) }\end{array}$ & OBM TPH (mg TPH $\mathbf{~ k g}^{-1} \mathbf{~ O B M ) ~}$ \\
\hline 22,000 & $117,403 \mathrm{C}$ \\
\hline 45,000 & $126,037 \mathrm{~B}$ \\
\hline 67,000 & $134,100 \mathrm{~A}$ \\
\hline 90,000 & $137,788 \mathrm{~A}$ \\
\hline
\end{tabular}

Table 5: Mean total petroleum hydrocarbon (TPH) concentration $(\mathrm{mg} \mathrm{TPH} \mathrm{kg}-1$ OBM) averaged across moisture regime and compared between sample day and $\mathrm{TPH}$ application rate. $\mathrm{OBM}$ loading rates were applied at 90,000, 67,000, 45,000, 22,000, and 0 (control) $\mathrm{kg} \mathrm{TPH} \mathrm{ha}^{-1}$. The treatments were subjected to four different moisture regimes. OBM was sampled at $0,7,30$, 60, and 91 days after application. Uppercase letters represent mean separation of TPH concentration between sampling days at each TPH application rate. Lowercase letters represent mean separation of TPH concentration between TPH application rates at each sampling day. Statistical decisions were made at $\mathrm{P}=0.05$.

\begin{tabular}{|c|c|}
\hline Sample Day & OBM TPH (mg TPH $\left.\mathbf{~ k g}^{-\mathbf{~}} \mathbf{\text { OBM}}\right)$ \\
\hline 0 & $161,558 \mathrm{~A}$ \\
\hline 7 & $139,705 \mathrm{~B}$ \\
\hline 30 & $129,652 \mathrm{C}$ \\
\hline 60 & $105,641 \mathrm{D}$ \\
\hline 91 & $107,605 \mathrm{D}$ \\
\hline
\end{tabular}

The main effect of sampling day (time) on overall TPH concentration was significant $(\mathrm{P} \leq 0.05)$ and is shown in further detail in Table 5 (averaged across all application rates and moisture regimes). As time increases, a significant decrease in TPH concentration was observed until day 60. Day 60 and 91 had a significantly lower TPH concentration than all previous sampling days; however there was no significant difference between day 60 and 91. Figure 1 and Table 6 illustrate the insignificant degradation between day 60 and 91 for each application rate. There was a large decrease in TPH concentration for all TPH rates up until day 60 . This plateau effect in degradation is likely due to the consumption of microbial nutrients, probably nitrogen, which inhibited further biodegradation of hydrocarbons. There were no significant differences in TPH concentrations between TPH application rates at day 0 or 7 . Significant difference between TPH rates occur at day 
30 and continue through day 91. TPH application rate 1 had the lowest TPH concentration followed by rate 2 and rate 3 , while rate 4 is not significantly higher than rate 3 . The TPH application rates 1 and 2 possess a higher proportion of OBM in contact with the soil surface, which may have improved degradation. Not only do TPH rates 3 and 4 have lower OBM to soil contact ratios, which limited biodegradation of TPH, but the excessive loading rates could have impeded oxygen flow into the soil which may have further restricted microbial degradation of hydrocarbons. TPH concentrations for all application rates at day 90 were higher than the Oklahoma Guardian thresholds established for non-sensitive soils $\left(46,000 \mathrm{mg} \mathrm{kg}^{-1}\right.$; [5]).

Table 6: Mean total petroleum hydrocarbon $(\mathrm{TPH})$ concentration $\left(\mathrm{mg} \mathrm{TPH} \mathrm{kg}^{-1} \mathrm{OBM}\right)$ averaged across moisture regime and compared between sample day and TPH application rate. OBM loading rates were applied at 90,000, 67,000, 45,000, 22,000, and 0 (control) kg $\mathrm{TPH} \mathrm{ha}{ }^{-1}$. The treatments were subjected to four different moisture regimes. OBM was sampled at 0, 7, 30, 60, and 91 days after application. Uppercase letters represent mean separation of TPH concentration between sampling days at each TPH application rate. Lowercase letters represent mean separation of TPH concentration between TPH application rates at each sampling day. Statistical decisions were made at $\mathrm{P}=0.05$.

\begin{tabular}{|c|c|c|c|c|c|}
\hline & \multicolumn{5}{|c|}{ TPH (mg TPH kg ${ }^{-1}$ OBM) } \\
\hline TPH rate (kg TPH ha-1) & Day 0 & Day 7 & Day 30 & Day 60 \\
\hline 22,000 & $161,558 \mathrm{Aa}$ & $136,549 \mathrm{Ba}$ & $112,346 \mathrm{Cc}$ & $88,738 \mathrm{Dc}$ & $102,749 \mathrm{Db}$ \\
\hline 45,000 & $161,558 \mathrm{Aa}$ & $136,047 \mathrm{Ba}$ & $126,705 \mathrm{Cb}$ & $103,127 \mathrm{Db}$ \\
\hline 67,000 & $161,558 \mathrm{Aa}$ & $140,816 \mathrm{Ba}$ & $140,394 \mathrm{Ba}$ & $115,926 \mathrm{Ca}$ \\
\hline 90,000 & $161558 \mathrm{Aa}$ & $145,409 \mathrm{Ba}$ & $139,163 \mathrm{Ba}$ & $119,272 \mathrm{Ca}$ & $123,540 \mathrm{Ca}$ \\
\hline
\end{tabular}

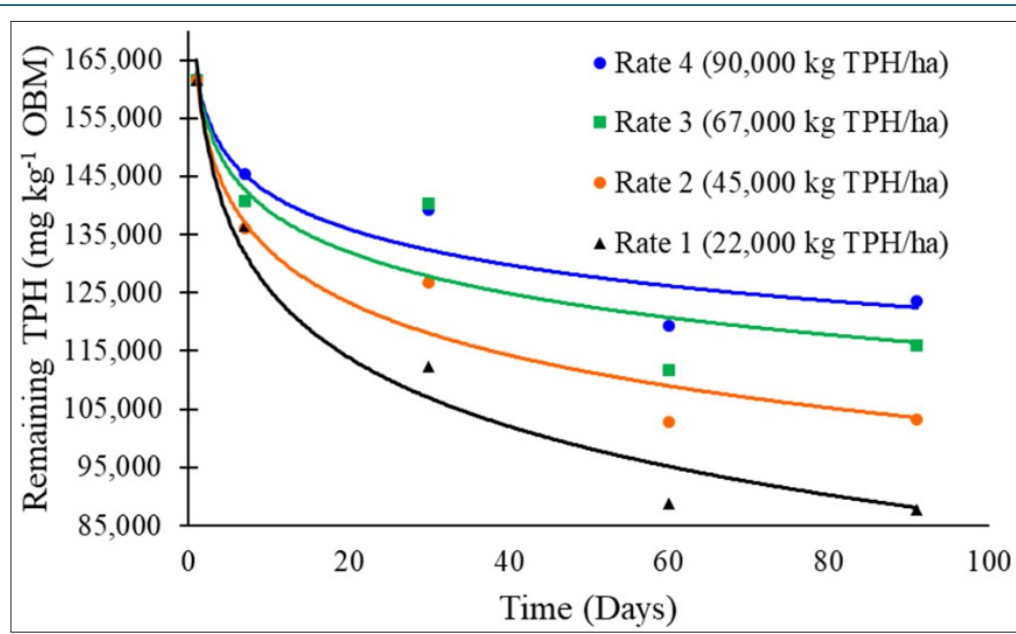

Figure 1: Mean remaining total petroleum hydrocarbon (TPH) concentrations in the OBM in $\mathrm{mg} \mathrm{kg}^{-1} \mathrm{OBM}$. OBM loading rates were applied at 90,000, 67,000, 45,000, 22,000, and 0 (control) $\mathrm{kg} \mathrm{TPH} \mathrm{ha-1.} \mathrm{The} \mathrm{treatments} \mathrm{were} \mathrm{subjected} \mathrm{to} \mathrm{four} \mathrm{different}$ moisture regimes. OBM was sampled at $0,7,30,60$, and 91 days after application. TPH values are for each sampling day and $\mathrm{TPH}$ application rate averaged over moisture regime.

\section{Changes in BTEX concentrations in the oil-base mud}

The main effect of sampling day on OBM BTEX concentration was significant at $\alpha=0.05$. The main effect of TPH rate and the twoway interaction of rate*day was also significant at $\alpha=0.05$ and is shown in Table 7, which provides a complete list of ANOVA results for the main effects and interactions. Table 8 shows a significant decrease in BTEX concentration ( $\mathrm{mg} \mathrm{kg}^{-1}$ ) for all BTEX constituents between day 0 and 7 . These decreases in BTEX concentrations over time can be attributed to volatilization, biodegradation, sorption to soil, and loss through leachate due to relatively high water solubility. The solubility of BTEX ranges from 174-1760 $\mathrm{mg} \mathrm{L}^{-1}$ (Sawyer et al., 2003). At day 7, the benzene concentration in the OBM was $0.06 \mathrm{mg}$ $\mathrm{kg}^{-1}$ and was the only compound of BTEX that exceeded regulations established by the U.S. EPA for risk to groundwater leaching (U.S. EPA, 1996). Concentrations of toluene, ethylbenzene, o-xylene, and $\mathrm{m}, \mathrm{p}$-xylene in the OBM were well below the EPA threshold limits for inhalation and groundwater risks. 
Table 7: ANOVA results for oil-base mud (OBM) benzene, ethylbenzene, toluene, o-xylene, and m, p-xylene (BTEX) concentrations in $\mathrm{mg} \mathrm{kg}^{-1} \mathrm{OBM}$ for the BTEX leaching column study. Results are significant when $(\operatorname{Pr} \leq 0.05)$.

\begin{tabular}{|c|c|c|c|c|c|c|}
\hline & & Benzene & Ethylbenzene & Toluene & o-Xylene & m, p-Xylene \\
\hline Variation & DF & \multicolumn{5}{|c|}{$\operatorname{Pr}>\mathrm{F}$} \\
\hline rep & 2 & 0.2719 & 0.1352 & 0.1841 & 0.1450 & 0.1331 \\
\hline rate & 3 & 0.1591 & $<0.0001$ & 0.0005 & $<0.0001$ & $<0.0001$ \\
\hline moisture & 3 & 0.7561 & 0.3655 & 0.3879 & 0.3127 & 0.3086 \\
\hline day & 1 & $<.0001$ & $<0.0001$ & $<0.0001$ & $<0.0001$ & $<0.0001$ \\
\hline rate*moisture & 9 & 0.5836 & 0.0969 & 0.2358 & 0.0792 & 0.0795 \\
\hline rate*day & 3 & 0.2112 & $<0.0001$ & 0.0004 & $<0.0001$ & $<0.0001$ \\
\hline moisture*day & 3 & 0.6667 & 0.1548 & 0.1952 & 0.1005 & 0.1151 \\
\hline rate*moisture*day & 9 & 0.3669 & 0.1124 & 0.2246 & 0.0787 & 0.0920 \\
\hline
\end{tabular}

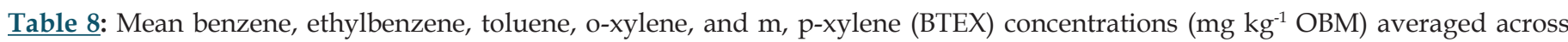
moisture regime and total petroleum hydrocarbon (TPH) application rate and compared between each sampling day. OBM loading rates were applied at 90,000,67,000, 45,000, 22,000, and 0 (control) $\mathrm{kg} \mathrm{TPH} \mathrm{ha-1.} \mathrm{The} \mathrm{treatments} \mathrm{were} \mathrm{subjected} \mathrm{to} \mathrm{four} \mathrm{different}$ moisture regimes. OBM BTEX was sampled at 0 , and 7 days after application. Lowercase letters represent mean separation for BTEX degradation $\left(\mathrm{mg} \mathrm{kg}^{-1} \mathrm{OBM}\right)$ between each sampling day. Statistical decisions were made at $\mathrm{P}=0.05$.

\begin{tabular}{|c|c|c|c|c|c|}
\hline \multicolumn{7}{|c|}{ BTEX $\left(\mathbf{m g ~ k g}^{-1} \mathbf{~ O B M}\right)$} \\
\hline Day & Benzene & Ethylbenzene & Toluene & o-Xylene & m, p-Xylene \\
\hline 0 & $2.65 \mathrm{a}$ & $34.99 \mathrm{a}$ & $23.28 \mathrm{a}$ & $63.53 \mathrm{a}$ & $94.08 \mathrm{a}$ \\
\hline 7 & $0.06 \mathrm{~b}$ & $4.40 \mathrm{~b}$ & $2.58 \mathrm{~b}$ & $7.80 \mathrm{~b}$ & $12.07 \mathrm{~b}$ \\
\hline
\end{tabular}

The main effect of TPH application rate $(\mathrm{kg}$ TPH ha-1) was significant $(\mathrm{Pr} \leq 0.05)$ for OBM BTEX concentration $\left(\mathrm{mg} \mathrm{kg} \mathrm{kg}^{-1}\right)$ for every BTEX constituent except for benzene (Table 9), when averaging over the two sampling days. TPH application rate 1 had significantly lower concentrations of ethylbenzene, toluene, o-xylene, and $\mathrm{m}$, p-xylene than all other TPH application rates. The TPH application rate 2 had the next lowest concentration values, which were significantly different than all other TPH application

Table 9: Mean benzene, ethylbenzene, toluene, o-xylene, and $\mathrm{m}$, p-xylene (BTEX) concentrations $\left(\mathrm{mg} \mathrm{kg}^{-1} \mathrm{OBM}\right)$ at each total petroleum hydrocarbon (TPH) application rate for the BTEX leaching column study. OBM loading rates were applied at 90,000, 67,000, 45,000, 22,000, and 0 (control) $\mathrm{kg} \mathrm{TPH} \mathrm{ha}^{-1}$. The treatments were subjected to four different moisture regimes. OBM BTEX was sampled at 0 , and 7 days after application. Lowercase letters represent mean separation for BTEX concentration $\left(\mathrm{mg} \mathrm{kg}^{-1} \mathrm{OBM}\right)$ between each TPH rate. Statistical decisions were made at $\mathrm{P}=0.05$.

\begin{tabular}{|c|c|c|c|c|c|}
\hline & \multicolumn{3}{|c|}{ BTEX (mg kg ${ }^{-1}$ OBM) } \\
\hline TPH rate $\left(\mathbf{k g ~ T P H}_{\mathbf{~ h a}}{ }^{-\mathbf{1}} \mathbf{)}\right.$ & Benzene & Ethylbenzene & Toluene & o-Xylene & m, $\mathbf{p}$-Xylene \\
\hline 22,000 & $1.33 \mathrm{a}$ & $17.96 \mathrm{c}$ & $11.97 \mathrm{~b}$ & $32.75 \mathrm{c}$ & $48.43 \mathrm{c}$ \\
\hline 45,000 & $1.33 \mathrm{a}$ & $19.20 \mathrm{~b}$ & $12.48 \mathrm{~b}$ & $35.09 \mathrm{~b}$ & $51.97 \mathrm{~b}$ \\
\hline 67,000 & $1.37 \mathrm{a}$ & $20.67 \mathrm{a}$ & $13.48 \mathrm{a}$ & $37.25 \mathrm{a}$ & $55.60 \mathrm{a}$ \\
\hline 90,000 & $1.39 \mathrm{a}$ & $20.96 \mathrm{a}$ & $13.79 \mathrm{a}$ & $37.56 \mathrm{a}$ & $56.29 \mathrm{a}$ \\
\hline
\end{tabular}

\section{Concentrations and loads of BTEX leached from applied} oil-base mud

The main effects of TPH rate, moisture regime, leaching event, and the interactions between each are shown in Table 10.The main effect of leaching event was significant $(\mathrm{P} \leq 0.05)$ for BTEX leachate concentrations $\left(\mu \mathrm{g} \mathrm{L}^{-1}\right)$ and is shown in added detail in Table 11, averaged over TPH application rate and moisture regime. Significantly higher concentrations of BTEX were measured at leaching event 1 when compared to leaching events 2 and 3. For every BTEX constituent except for o-xylene, leaching event 1 was rates. TPH application rates 3 and 4 had the highest concentrations of BTEX and were both significantly higher than TPH rates 1 and 2, although not significantly different from each other. Similar trends were noted regarding TPH concentrations (Table 4). Higher BTEX concentrations (i.e. lower degradation) at the highest application rates (3 and 4) likely occurred for the same reasons as previously discussed for TPH degradation. 
Table 10: ANOVA results for benzene, ethylbenzene, toluene, o-xylene, and $\mathrm{m}, \mathrm{p}$-xylene (BTEX) leachate concentrations in $\left(\mu \mathrm{g} \mathrm{L}^{-1}\right)$ for the BTEX leaching column study. Results significant when $(\operatorname{Pr} \leq 0.05) . \quad \mathrm{LE}=$ "leaching event".

\begin{tabular}{|c|c|c|c|c|c|c|}
\hline & & Benzene & Ethylbenzene & Toluene & o-Xylene & m, p-Xylene \\
\hline Source & DF & & & \multicolumn{2}{|c|}{ Pr $>$ F } \\
\hline rep & 2 & 0.085 & 0.1017 & 0.0924 & 0.144 & 0.0717 \\
\hline rate & 4 & 0.031 & 0.0994 & 0.1102 & 0.0059 & $<.0747$ \\
\hline moisture & 3 & $<0.0001$ & $<0.0001$ & $<0.0001$ & $<0.0001$ & $<0.0001$ \\
\hline LE & 2 & $<0.0001$ & $<0.0001$ & $<0.0001$ & 0.2328 & 0.1163 \\
\hline rate*moisture & 12 & 0.005 & 0.1310 & 0.0752 & 0.0034 & 0.0496 \\
\hline rate*LE & 8 & 0.0116 & 0.0702 & 0.0839 & $<0.0001$ \\
\hline moisture*LE & 6 & $<0.0001$ & $<0.0001$ & $<0.0001$ & $<001$ & $<0.0001$ \\
\hline rate*moisture*LE & 24 & 0.0005 & 0.1104 & 0.0491 & 0.2416 & 0.1032 \\
\hline
\end{tabular}

Table 11: Mean benzene, ethylbenzene, toluene, o-xylene, and m, p-xylene (BTEX) leachate concentrations $\left(\mu g \mathrm{~L}^{-1}\right)$ averaged over total petroleum hydrocarbon (TPH) application rate and moisture regimes and compared between leaching events. For the BTEX leaching column study. OBM loading rates were applied at 90,000, 67,000, 45,000, 22,000, and 0 (control) kg TPH ha- ${ }^{-1}$ The treatments were subjected to four different moisture regimes which had one leaching event per month. Lowercase letters represent mean separation between leaching events for each BTEX constituent concentration $\left(\mu \mathrm{g} \mathrm{L}^{-1}\right)$. Statistical decisions were made at $\mathrm{P}=0.05$. LE $=$ "leaching event".

\begin{tabular}{|c|c|c|c|c|c|}
\hline LE & Benzene ( $\left.\mu \mathrm{g} \mathrm{L}^{-1}\right)$ & Ethylbenzene ( $\left.\mu \mathrm{g} \mathrm{L}^{-1}\right)$ & Toluene ( $\left.\mu \mathrm{g} \mathrm{L}^{-1}\right)$ & o-Xylene ( $\left.\mu \mathrm{g} \mathrm{L}^{-1}\right)$ & m, p-Xylene $\left(\mu \mathrm{g} \mathrm{L}^{-1}\right)$ \\
\hline 1 & $0.50 \mathrm{a}$ & $2.12 \mathrm{a}$ & $3.77 \mathrm{a}$ & $3.27 \mathrm{a}$ & $4.89 \mathrm{a}$ \\
\hline 2 & $0.00 \mathrm{~b}$ & $0.00 \mathrm{~b}$ & $0.00 \mathrm{~b}$ & $0.15 b$ & $0.00 \mathrm{~b}$ \\
\hline 3 & $0.00 \mathrm{~b}$ & $0.00 \mathrm{~b}$ & $0.00 \mathrm{~b}$ & $0.00 \mathrm{~b}$ & $0.00 \mathrm{~b}$ \\
\hline
\end{tabular}

The main effect of moisture regime was significant ( $\mathrm{P} \leq 0.05) \quad$ was averaged over the first sampling day of each month (day 0,35 , for BTEX leachate concentrations $\left(\mu \mathrm{g} \mathrm{L}^{-1}\right)$ and is presented in further detail in Table 12. Moisture regime 1 ( 0 wetting events per month) showed significantly higher BTEX concentrations than all other moisture regimes that received non-leaching wetting events. The leachate concentrations of each BTEX constituent at moisture regime 2, 3, and 4 were statistically the same. However, the highest concentrations of BTEX observed in the leachate for moisture and 63). Specifically, moisture regime 1 was sampled (i.e. leached) on day 0,35 , and 63 and only had BTEX concentrations above $0 \mu \mathrm{g}$ $\mathrm{L}^{-1}$ on day 0 , which were the highest for the entire study. The highest BTEX leachate concentrations from day 0 thus caused moisture regime 1 to be significantly higher than the other moisture regimes. Again, this shows the importance of time on BTEX degradation, volatilization, and sorption to the soil. regime 1 is likely due to the fact that values from moisture regime 1

Table 12: Mean ethylbenzene and toluene leachate concentrations $\left(\mu \mathrm{g} \mathrm{L}^{-1}\right)$ averaged over total petroleum hydrocarbon $(\mathrm{TPH})$ application rate and leaching events and compared between moisture regimes. OBM loading rates were applied at 90,000, 67,000, $45,000,22,000$, and 0 (control) $\mathrm{kg} \mathrm{TPH} \mathrm{ha}^{-1}$. The treatments were subjected to four different moisture regimes which had one leaching event per month. Uppercase letters represent mean separation for ethylbenzene and toluene between moisture regimes. Statistical decisions were made at $\mathrm{P}=0.05$.

\begin{tabular}{|c|c|c|c|c|}
\hline & Moisture 1 & Moisture 2 & Moisture 3 & Moisture 4 \\
\hline Benzene $\left(\mu \mathrm{g} \mathrm{L}^{-1}\right)$ & $0.67 \mathrm{~A}$ & $0.00 \mathrm{~B}$ & $0.00 \mathrm{~B}$ & $0.00 \mathrm{~B}$ \\
\hline Ethylbenzene $\left(\mu \mathrm{g} \mathrm{L}^{-1}\right)$ & $2.65 \mathrm{~A}$ & $0.09 \mathrm{~B}$ & $0.04 \mathrm{~B}$ \\
\hline Toluene $\left(\mu \mathrm{g} \mathrm{L}^{-1}\right)$ & $4.91 \mathrm{~A}$ & $0.06 \mathrm{~B}$ & $0.02 \mathrm{~B}$ & $0.03 \mathrm{~B}$ \\
\hline o-Xylene $\left(\mu \mathrm{g} \mathrm{L}^{-1}\right)$ & $3.51 \mathrm{~A}$ & $0.43 \mathrm{~B}$ & $0.34 \mathrm{~B}$ & $0.28 \mathrm{~B}$ \\
\hline $\mathrm{m}, \mathrm{p}$-Xylene $\left(\mu \mathrm{g} \mathrm{L}^{-1}\right)$ & $6.06 \mathrm{~A}$ & $0.12 \mathrm{~B}$ & $0.15 \mathrm{~B}$ & $0.18 \mathrm{~B}$ \\
\hline
\end{tabular}


Table 13: Mean benzene and toluene leachate concentrations $\left(\mu \mathrm{g} \mathrm{L}^{-1}\right)$ at moisture regime one comparing total petroleum hydrocarbon (TPH) application rates and leaching events for the BTEX leaching column study. OBM loading rates were applied at 90,000, $67,000,45,000,22,000$, and 0 (control) $\mathrm{kg} \mathrm{TPH} \mathrm{ha}^{-1}$. The treatments were subjected to four different moisture regimes which had one leaching event per month. Uppercase letters represent mean separation of benzene and toluene leachate concentrations between $\mathrm{TPH}$ application rates at each leaching event within moisture regime one. Lowercase letters represent mean separation of benzene and toluene leachate concentrations between leaching events at each TPH application rate within moisture regime one. Statistical decisions were made at $\mathrm{P}=0.05$.

\begin{tabular}{|c|c|c|c|c|c|}
\hline TPH Rate (kg TPH ha') & $\mathbf{0}$ & 22,000 & 45,000 & 67,000 & 90,000 \\
\hline Leaching Event & \multicolumn{5}{|c|}{ Benzene $\left(\mu \mathrm{g} \mathrm{L}^{-1}\right)$} \\
\hline 1 & $0.00 \mathrm{Ca}$ & $0.44 \mathrm{BCa}$ & $2.48 \mathrm{ABCa}$ & $2.92 \mathrm{ABa}$ & $4.20 \mathrm{Aa}$ \\
\hline 2 & $0.00 \mathrm{Aa}$ & $0.00 \mathrm{Aa}$ & $0.00 \mathrm{Ab}$ & $0.00 \mathrm{Aa}$ & $0.00 \mathrm{Ab}$ \\
\hline 3 & $0.00 \mathrm{Aa}$ & $0.00 \mathrm{Aa}$ & $0.00 \mathrm{Ab}$ & $0.00 \mathrm{Aa}$ & $0.00 \mathrm{Ab}$ \\
\hline Leaching Event & \multicolumn{5}{|c|}{ Toluene $\left(\mu \mathrm{g} \mathrm{L}^{-1}\right)$} \\
\hline 1 & $0.00 \mathrm{Ba}$ & 6.37ABa & $15.56 \mathrm{ABa}$ & 24.72Aa & $27.00 \mathrm{Aa}$ \\
\hline 2 & $0.00 \mathrm{Aa}$ & $0.00 \mathrm{Aa}$ & $0.00 \mathrm{Ab}$ & $0.00 \mathrm{Aa}$ & $0.00 \mathrm{Ab}$ \\
\hline 3 & $0.00 \mathrm{Aa}$ & $0.00 \mathrm{Aa}$ & $0.00 \mathrm{Ab}$ & $0.00 \mathrm{Aa}$ & $0.00 \mathrm{Ab}$ \\
\hline
\end{tabular}

The three-way interaction of TPH rate by moisture regime by leaching event was significant $(\mathrm{P} \leq 0.05)$ for benzene and toluene leachate concentrations ( $\mu \mathrm{g} \mathrm{L}^{-1}$; Table 13). Moisture regime 1 is the only regime shown in Table 13 because this was the only moisture regime that had significant amounts of BTEX in the leachate (Table 12). A general trend of increasing concentrations of benzene and toluene in leachate was observed as the rate of TPH application increased, for leaching event 1 . Leaching events 2 and 3 have no detectable concentrations of benzene or toluene in the leachate. By the time leaching events 2 and 3 occurred, all amounts of benzene and toluene were lost via microbial degradation, volatilization, and

Table 14: ANOVA results for benzene, ethylbenzene, toluene, o-xylene, and m, p-xylene (BTEX) leachate loads ( $\mu \mathrm{g}$ ) for the BTEX leaching study. Results were significant when $(\operatorname{Pr} \leq 0.05) . \mathrm{LE}=$ "leaching event".

\begin{tabular}{|c|c|c|c|c|c|c|}
\hline & & Benzene & Ethylbenzene & Toluene & o-xylene & m, p-xylene \\
\hline Variation & DF & \multicolumn{5}{|c|}{$\operatorname{Pr}>F$} \\
\hline rep & 2 & 0.0981 & 0.1569 & 0.1057 & 0.3109 & 0.0896 \\
\hline rate & 4 & 0.0051 & 0.0239 & 0.0340 & $<0.0001$ & 0.0094 \\
\hline moisture & 3 & $<0.0001$ & $<0.0001$ & $<0.0001$ & $<0.0001$ & $<0.0001$ \\
\hline LE & 2 & $<0.0001$ & $<0.0001$ & $<0.0001$ & $<0.0001$ & $<0.0001$ \\
\hline rate*moisture & 12 & 0.0002 & 0.0595 & 0.0176 & 0.2637 & 0.0535 \\
\hline rate*LE & 8 & 0.0005 & 0.0061 & 0.0127 & $<0.0001$ & 0.0016 \\
\hline moisture*LE & 6 & $<0.0001$ & $<0.0001$ & $<0.0001$ & $<0.0001$ & $<0.0001$ \\
\hline rate*moisture*LE & 24 & $<0.0001$ & 0.0274 & 0.0044 & 0.1646 & 0.0290 \\
\hline
\end{tabular}


Table 15: Mean benzene, ethylbenzene, toluene, o-xylene, and $\mathrm{m}, \mathrm{p}$-xylene (BTEX) leachate loads at moisture regime one, comparing $\overline{\mathrm{TPH}}$ application rates and leaching events. OBM loading rates were applied at 90,000, 67,000, 45,000, 22,000, and 0 (control) $\mathrm{kg}$ TPH $\mathrm{ha}^{-1}$. The treatments were subjected to four different moisture regimes which had one leaching event per month. " $t^{\prime \prime}-\mathrm{o}-\mathrm{xylene}$ was not significant at $\mathrm{P}=0.05$. Uppercase letters represent mean separation of BTEX loads $(\mu \mathrm{g})$ between TPH application rates at each leaching event, for moisture regime one. Lowercase letters represent mean separation of BTEX loads ( $\mu \mathrm{g})$ between leaching events at each TPH rate, for moisture regime one. Statistical decisions were made at $\mathrm{P}=0.05$.

\begin{tabular}{|c|c|c|c|c|c|}
\hline \multicolumn{6}{|c|}{ Moisture Regime One } \\
\hline TPH Rate (kg TPH ha-1) & 0 & 22,000 & 45,000 & 67,000 & 90,000 \\
\hline Leaching Event & \multicolumn{5}{|c|}{ Benzene $(\mu \mathrm{g})$} \\
\hline 1 & $0.00 \mathrm{Ca}$ & $0.21 \mathrm{BCa}$ & $1.13 \mathrm{ABCa}$ & $1.22 \mathrm{ABa}$ & $2.10 \mathrm{Aa}$ \\
\hline 2 & $0.00 \mathrm{Aa}$ & $0.00 \mathrm{Aa}$ & $0.00 \mathrm{Ab}$ & $0.00 \mathrm{Aa}$ & $0.00 \mathrm{Ab}$ \\
\hline 3 & $0.00 \mathrm{Aa}$ & $0.00 \mathrm{Aa}$ & $0.00 \mathrm{Ab}$ & $0.00 \mathrm{Aa}$ & $0.00 \mathrm{Ab}$ \\
\hline Leaching Event & \multicolumn{5}{|c|}{ Ethylbenzene $(\mu \mathrm{g})$} \\
\hline 1 & $0.00 \mathrm{Ca}$ & $1.75 \mathrm{BCa}$ & 3.91ABCa & $5.30 \mathrm{ABa}$ & 7.15Aa \\
\hline 2 & $0.00 \mathrm{Aa}$ & $0.00 \mathrm{Aa}$ & $0.00 \mathrm{Ab}$ & $0.00 \mathrm{Aa}$ & $0.00 \mathrm{Ab}$ \\
\hline 3 & $0.00 \mathrm{Aa}$ & $0.00 \mathrm{Aa}$ & $0.00 \mathrm{Ab}$ & $0.00 \mathrm{Aa}$ & $0.00 \mathrm{Ab}$ \\
\hline Leaching Event & \multicolumn{5}{|c|}{ Toluene $(\mu \mathrm{g})$} \\
\hline 1 & $0.00 \mathrm{Ca}$ & $2.93 \mathrm{BCa}$ & 7.00ABCa & $10.22 \mathrm{ABa}$ & $13.38 \mathrm{Aa}$ \\
\hline 2 & $0.00 \mathrm{Aa}$ & $0.00 \mathrm{Aa}$ & $0.00 \mathrm{Ab}$ & $0.00 \mathrm{Aa}$ & $0.00 \mathrm{Aa}$ \\
\hline 3 & $0.00 \mathrm{Aa}$ & $0.00 \mathrm{Aa}$ & $0.00 \mathrm{Ab}$ & $0.00 \mathrm{Aa}$ & $0.00 \mathrm{Aa}$ \\
\hline Leaching Event & \multicolumn{5}{|c|}{ †o-Xylene ( $\mu \mathrm{g})$} \\
\hline 1 & 0.00 & 2.66 & 5.60 & 6.49 & 8.74 \\
\hline 2 & 0.00 & 0.00 & 0.00 & 0.00 & 0.57 \\
\hline 3 & 0.00 & 0.00 & 0.00 & 0.00 & 0.00 \\
\hline Leaching Event & \multicolumn{5}{|c|}{$\mathrm{m}, \mathrm{p}$-Xylene $(\mu \mathrm{g})$} \\
\hline 1 & $0.00 \mathrm{Ca}$ & 4.30BCa & $9.34 \mathrm{ABCa}$ & $11.72 \mathrm{ABa}$ & $16.06 \mathrm{Aa}$ \\
\hline 2 & $0.00 \mathrm{Aa}$ & $0.00 \mathrm{Aa}$ & $0.00 \mathrm{Ab}$ & $0.00 \mathrm{Aa}$ & $0.00 \mathrm{Ab}$ \\
\hline 3 & $0.00 \mathrm{Aa}$ & $0.00 \mathrm{Aa}$ & $0.00 \mathrm{Ab}$ & $0.00 \mathrm{Aa}$ & $0.00 \mathrm{Ab}$ \\
\hline
\end{tabular}

\section{Leachate electrical conductivity and $\mathrm{pH}$}

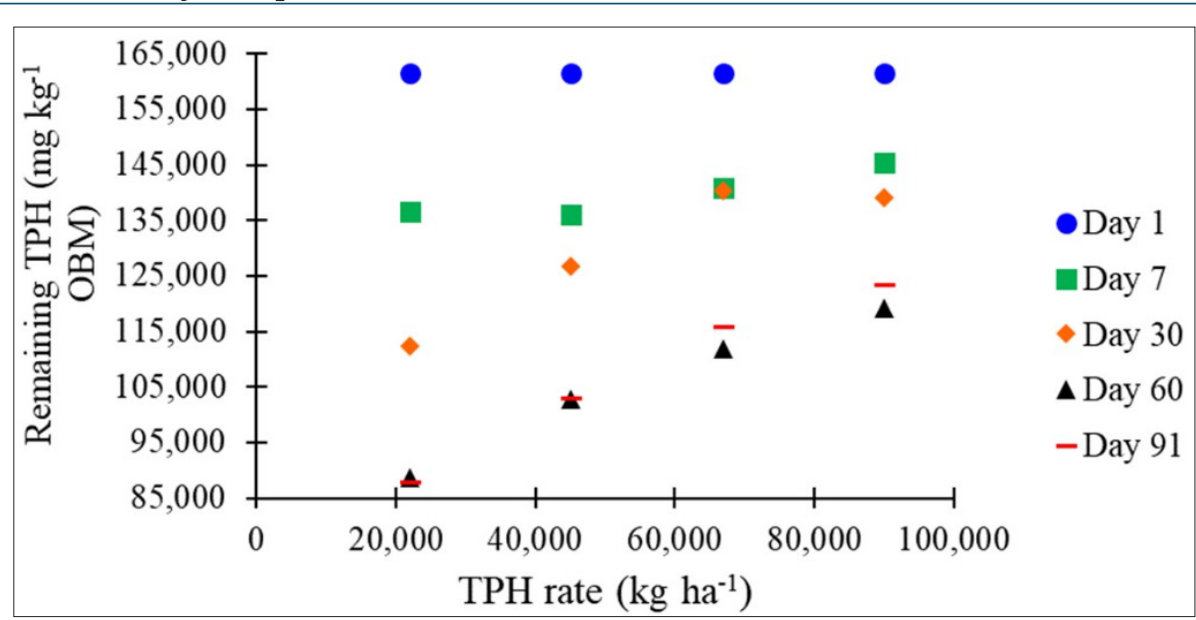

Figure 2: Mean remaining total petroleum hydrocarbon (TPH) concentrations in oil-base mud (mg $\left.\mathrm{kg}^{-1} \mathrm{OBM}\right)$ for the BTEX leaching study. OBM loading rates were applied at 90,000, 67,000, 45,000, 22,000, and 0 (control) kg TPH ha-1. The treatments were subjected to four different moisture regimes. OBM was sampled at 0, 7, 30, 60, and 91 days after application. Remaining TPH concentrations are shown for each TPH application rate, and sampling time, and are averaged over moisture regime. 
The main effects of TPH application rate, moisture regime, and leaching event on leachate EC, and interactions between variables are shown in Table 16. The two-way interaction of TPH rate by leaching event was significant $(\mathrm{P} \leq 0.05)$ for leachate $\mathrm{EC}\left(\mathrm{mS} \mathrm{cm}^{-1}\right)$ and is shown in greater detail in Table 17. A significant increase in leachate EC is observed with increasing TPH application rates for each leaching event. As TPH rate increased, the total amount of salts applied from the OBM (Table 2) was greater, which led to higher leachate EC values as the salts dissolved with the leaching water?
A general trend of increasing leachate EC with leaching event was observed for each TPH application rate except for the control which received no amendment. The leachate EC can serve as an indicator of the mobility of soluble species in the solution and can be used to indicate the leaching front for soluble species. Due to the fact that leachate EC continues to increase at each leaching event while BTEX concentrations do not (Table 11), this confirms that the BTEX has either degraded or sorbed to the soil or was lost via volatilization (Figure 2).

Table 16: ANOVA results for leachate electrical conductivity $\left(\mathrm{EC} ; \mathrm{mS} \mathrm{cm}^{-1}\right)$ and $\mathrm{pH}$ for the BTEX leaching column study. Results were significant when $(\operatorname{Pr} \leq 0.05)$. LE = "leaching event".

\begin{tabular}{|c|c|c|c|}
\hline \multicolumn{2}{|c|}{} & EC $\left(\mathrm{mS} \mathrm{cm}^{-1}\right)$ & \multicolumn{2}{|c|}{ PH $>$ F } \\
\hline Source & DF & $<0.0001$ & 0.0782 \\
\hline rep & 2 & $<0.0001$ & 0.5053 \\
\hline rate & 4 & $<0.0001$ & 0.0005 \\
\hline moisture & 3 & $<0.0001$ & $<0.0001$ \\
\hline LE & 2 & 0.2153 & 0.2817 \\
\hline rate*moisture & 12 & $<0.0001$ & 0.0044 \\
\hline rate*LE & 8 & $<0.0001$ & $<0.0001$ \\
\hline moisture*LE & 6 & 0.1714 & 0.2605 \\
\hline
\end{tabular}

Table 17: Mean leachate electrical conductivity $\left(\mathrm{EC} ; \mathrm{mS} \mathrm{cm}^{-1}\right)$ averaged across moisture regime comparing total petroleum hydrocarbon (TPH) application rates and leaching events (LE). OBM loading rates were applied at 90,000, 67,000, 45,000, 22,000, and 0 (control) $\mathrm{kg} \mathrm{TPH} \mathrm{ha}{ }^{-1}$. The treatments were subjected to four different moisture regimes which had one leaching event per month. Uppercase letters represent mean separation of leachate EC $\left(\mathrm{mS} \mathrm{cm}^{-1}\right)$ between leaching events at each TPH application rate. Lowercase letters represent mean separation between TPH application rates at each leaching event. Statistical decisions were made at P $=0.05$.

\begin{tabular}{|c|c|c|c|}
\hline TPH Rate $\left(\mathbf{k g}\right.$ TPH ha $\left.{ }^{-1}\right)$ & LE 1 & LE 2 & LE 3 \\
\hline 0 & $1.00 \mathrm{Ac}$ & $1.09 \mathrm{Ab}$ & $0.71 \mathrm{Bc}$ \\
\hline 22,000 & $1.08 \mathrm{Abc}$ & $1.24 \mathrm{Bab}$ & $1.34 \mathrm{Bb}$ \\
\hline 45,000 & $1.15 \mathrm{Ab}$ & $1.42 \mathrm{Aa}$ & $1.72 \mathrm{Ba}$ \\
\hline 67,000 & $1.18 \mathrm{Ab}$ & $1.38 \mathrm{Ba}$ & $1.79 \mathrm{Ba}$ \\
\hline 90,000 & $1.33 \mathrm{Aa}$ & $1.41 \mathrm{Aa}$ & \\
\hline
\end{tabular}

The main effects of moisture regime and leaching events, and the interactions of TPH rate*leaching event and moisture regimes*leaching events were significant at $\alpha=0.05$ for the $\mathrm{pH}$ of the leachate. Table 16 provides a complete list of ANOVA results for all main effects and interactions for leachate $\mathrm{pH}$. The main effect of leaching event was significant $(\mathrm{P} \leq 0.05)$ for leachate $\mathrm{pH}$ and is shown in more detail in Figure 3. There were significant increases in leachate $\mathrm{pH}$ with each additional leaching event. However, TPH application rate had no effect on leachate $\mathrm{pH}$ because the $\mathrm{pH}$ of the control leachate also had significant increases in $\mathrm{pH}$ with each additional leaching event (Figure 4). The increase in leachate $\mathrm{pH}$ across the leaching events was likely due to the alkaline $\mathrm{pH}$ (8.23) of the water that was used to leach the soil columns. As time progressed throughout leaching events, the leachate $\mathrm{pH}$ approached the higher $\mathrm{pH}$ values of the water that was used to leach the soil columns(Table 18). 


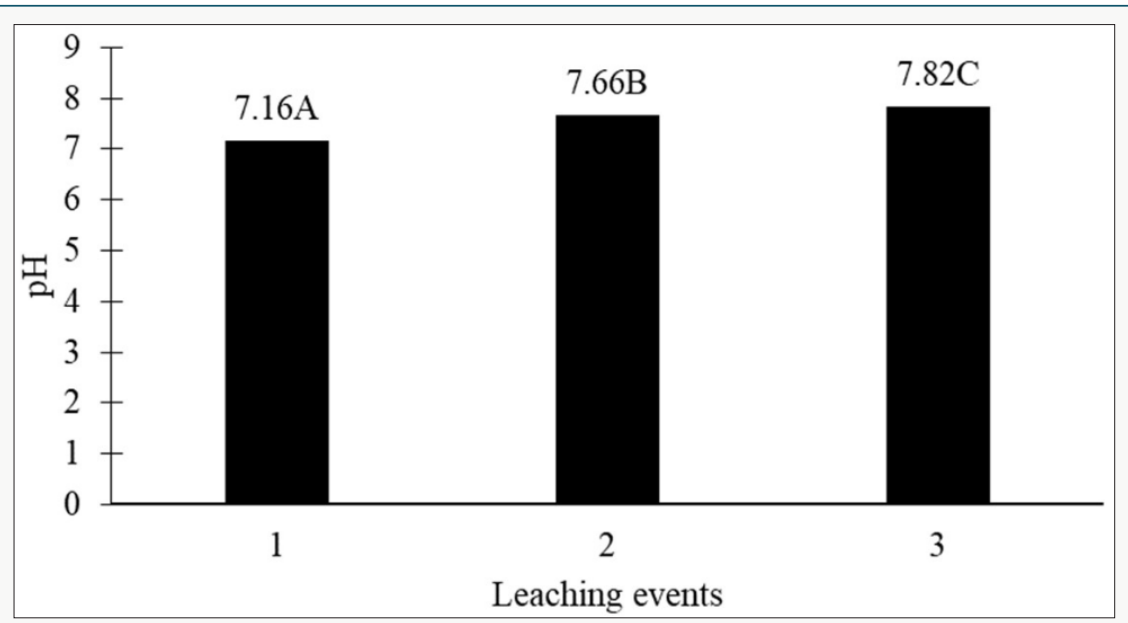

Figure 3: Mean leachate $\mathrm{pH}$ comparing each leaching event for the BTEX leaching column study. OBM loading rates were applied at 90,000, 67,000, 45,000, 22,000, and 0 (control) $\mathrm{kg} \mathrm{TPH} \mathrm{ha}^{-1}$. The treatments were subjected to four different moisture regimes which had one leaching event per month. Leachate $\mathrm{pH}$ values are averaged over total petroleum hydrocarbon (TPH) rate and moisture regimes. Uppercase letters represent mean separation of leachate $\mathrm{pH}$ between leaching events. Statistical decisions were made at $\mathrm{P}=0.05$.

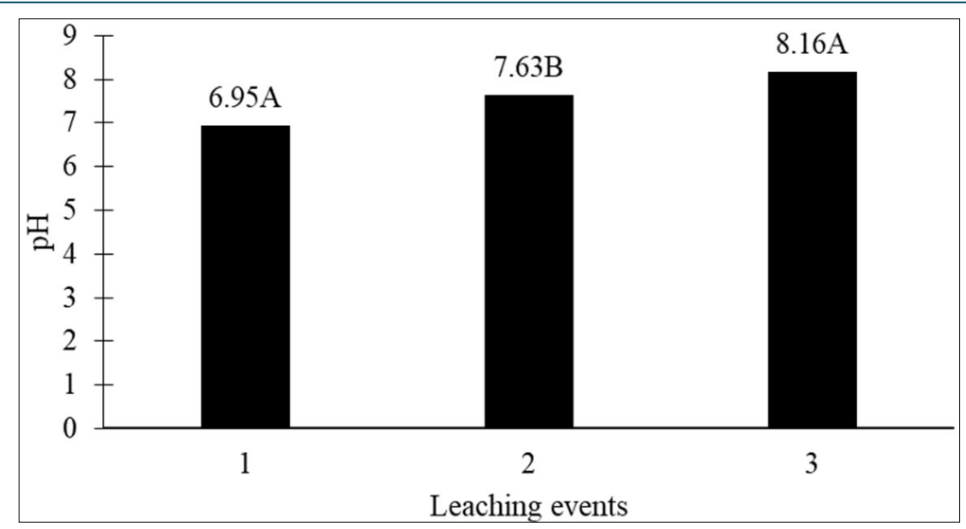

Figure 4: Mean leachate $\mathrm{pH}$ of the control (no OBM) comparing each leaching event for the BTEX leachate column study. OBM loading rates were applied at 90,000, 67,000, 45,000, 22,000, and 0 (control) $\mathrm{kg} \mathrm{TPH} \mathrm{ha}^{-1}$. The treatments were subjected to four different moisture regimes which had one leaching event per month. Leachate $\mathrm{pH}$ was averaged over moisture regimes. Uppercase letters represent mean separation of leachate $\mathrm{pH}$ between leaching events. Statistical decisions were made at $\mathrm{P}=$ 0.05 .

Table 18: Mean leachate $\mathrm{pH}$ values averaged over total petroleum hydrocarbon (TPH) rate, comparing moisture regimes and leaching

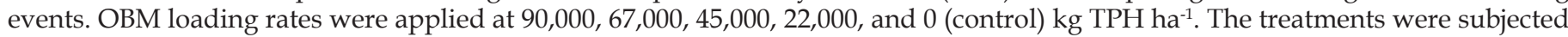
to four different moisture regimes which had one leaching event per month. Uppercase letters represent mean separation of leachate $\mathrm{pH}$ between moisture regimes at each leaching event. Lowercase letters represent mean separation of leachate $\mathrm{pH}$ between leaching events at each moisture regime. Statistical decisions were made at $\mathrm{P}=0.05$.

\begin{tabular}{|c|c|c|c|c|}
\hline \multicolumn{5}{|c|}{ BTEX leachate pH } \\
\hline Leaching Event & Moisture 1 & Moisture 2 & Moisture 3 & Moisture 4 \\
\hline 1 & $7.63 \mathrm{Ab}$ & $7.09 \mathrm{Bc}$ & $6.95 \mathrm{Bb}$ & $7.01 \mathrm{Bb}$ \\
\hline 2 & $7.31 \mathrm{Cb}$ & $8.06 \mathrm{Aa}$ & $7.53 \mathrm{BCa}$ & $7.73 \mathrm{ABa}$ \\
\hline 3 & $8.21 \mathrm{Aa}$ & $7.62 \mathrm{Bb}$ & $7.61 \mathrm{Ba}$ & $7.78 \mathrm{Ba}$ \\
\hline
\end{tabular}




\section{Summary and Implications}

The OBM was applied in this study at rates much greater than what is allowed by current OCC regulations, and were not incorporated in order to examine the worst-case scenario regarding environmental impact. The OBM used in this soil column leachate study did not possess heavy metal concentrations beyond normal soil concentrations. Benzene concentrations in the raw OBM $(2.65$ mg kg-1) were higher than the EPA threshold limits established for inhalation ( $\left.0.8 \mathrm{mg} \mathrm{kg}^{-1}\right)$ and leaching to groundwater $(0.03 \mathrm{mg} \mathrm{kg}$ $\left.{ }^{1}\right)$. Regardless, by day 7 , the BTEX concentration in the mud had decreased by $88 \%$ and benzene only leached out during the first leaching event which produced benzene concentrations that were acceptable according to USEPA drinking water standards. This was surprising due to the high benzene content in the OBM, which greatly exceeded USEPA risk levels for groundwater leaching, the short column length, and high hydraulic conductivity of the soil utilized. An explanation for this is found in closer examination of the assumptions made in creation of the USEPA concentration thresholds for leaching to groundwater i.e. the assumption that there is no degradation of benzene and that the entire soil profile contains benzene from the surface to the groundwater interface. As expected, increased OBM application rates resulted in higher leachate benzene concentrations.

All leachate BTEX concentrations were below drinking water thresholds. No trace metals were detected in leachate. Part of the reason for non-detectable BTEX concentrations in leachate after the initial leaching event on day 0 , was due to $88 \%$ degradation of BTEX in the applied OBM by day 7. Based on the results of this study, there is little risk of BTEX leaching to ground water through land application of OBM. However, it is unknown if this lack of BTEX movement was due to extreme soil sorption, degradation, or volatilization. The main effect of TPH application rate had the greatest effect on TPH degradation, BTEX concentrations in the OBM, leachate BTEX concentrations and loads, and leachate EC. As the rate of TPH increased, a decrease in hydrocarbon degradation was observed due to the higher OBM to soil ratio that limited oxygen inflow and microbial degradation. A plateau effect on biodegradation of TPH was seen at day 60 and continued throughout day 91. At that point, we hypothesize that the microorganisms had likely consumed all of the nutrients and could no longer biodegrade the TPH.

Therefore, applying a source of fertilizer and increasing the surface area to volume ratio of the OBM via disking or using a bulking agent is important when considering microbial degradation of TPH. During the study, the maximum TPH degradation that occurred was 35\%, which occurred from the lowest TPH application rate. Leachate EC increased as TPH rate increased due to higher loads of soluble salts. Leachate EC also increased at each leaching event as opposed to the decreasing BTEX concentrations with additional leaching event, which confirmed that the BTEX had volatilized, sorbed to the soil, or degraded. The main effect of TPH rate had no effect on leachate $\mathrm{pH}$. Further studies should be conducted in order to quantify BTEX volatilization that may occur with land application of OBM, and deter mine if there is any possible human health risks associated with any potential volatilization.

\section{References}

1. American Petroleum Institute (2013) Environmental Expenditures by the U.S. Oil and Natural Gas Industry. American Petroleum Institute Statistics, Washington DC, USA.

2. American Petroleum Institute (2000) Overview of Exploration and Production Waste Volumes and Waste Management Practices in the United States. American Petroleum Institute Statistics, Washington DC, USA.

3. Ukeles SD, Grinbaum B (2004) Drilling Fluids. Kirk-Othmer Encyclopedia of Chemical Technology. John Wiley \& Sons, Inc., Hoboken NJ.

4. Moseley H (1983) Summary and analysis of API onshore drilling mud and produced water environmental studies. American Petroleum Institute, Production Department, Washington DC, USA.

5. Barker G, K Armstrong, T Adamson (1992) Land treatment of petroleum hydrocarbon-based drill cuttings: pilot scale field study. Society of Petroleum Engineers $67^{\text {th }}$ Annual Technical Conference and Exhibition. Washington, DC, USA.

6. Onwukwe SN, wakaudu M (2012) Drilling Wastes Generation and Management Approach. Int. J. Eviron. Sci Devel 3(3): 252-256.

7. ATSDR (1999) Toxicological Profile for Total Petroleum Hydrocarbons (TPH).

8. Sawyer CN, McCarty PL, Parkin GF (2002) Chemistry for Environmental Engineering and Science. $5^{\text {th }}$ ed. McGraw Hill.

9. Penet S, R Marchal, A Sghir, F Monot (2004) Biodegradation of hydrocarbon cuts used for diesel oil formulation. Appl Microbiol Biotechnol 66(1): 40-47.

10. Dou J, Liu X, Hu Z (2007) Anaerobic BTEX degradation in soil bioaugmented with mixed consortia under nitrate reducing conditions. Journal of Environmental Sciences 20(5): 585-592.

11. SAS Institute Inc (2011) SAS/SHARE® 9.3 User's Guide. Cary, NC: SAS Institute Inc.

12. Sims JL, Sims RC, Matthews JE (1989) Bioremediation of Contaminated Surface Soils.

13. US EPA (1996) Aromatic and halogenated volatiles by gas chromatography using photoionization and/or electrolytic conductivity detectors. Method 8021B. Washington, DC: US Environmental Protection Agency.

14. US EPA (1996) Generic SSLs for The Residential and Commercial/ Industrial Scenarios. Washington DC: US Environmental Protection Agency.

15. Billingsley P (2003) Oklahoma's new Guardian program guidance for the assessment and cleanup of complex crude oil and condensate spills. Society of petroleum engineers annual conference: Exploration and production environmental conference. San Antonio, TX, USA.

16. US EPA (2014) A plain English guide to the EPA part 503 bio solids rule.

17. US EPA (1992) Ground Water Issue. Behavior of Metals in Soils. Washington, DC: US Environmental Protection Agency.

18. US EPA (1986) Acid digestion of sediments, sludges, and soils. Section methods. Method 3050. In SW-846. Test methods for evaluating solid waste.

19. US EPA (2009) Drinking water standards-quick reference guides. 816F-09-004 rule. 
CC) This work is licensed under Creative To Submit Your Article Click Here:

Submit Article

Assets of Publishing with us
Podern Approaches in Oceanography and
Petrochemical Sciences

